\title{
院内感染対策用内装システ RESEARCH AND DEVELOPMENT 厶の開発研究 \\ OF INTERIOR FINISHING SYSTEM TO PREVENT HOSPITAL INFECTIONS
}

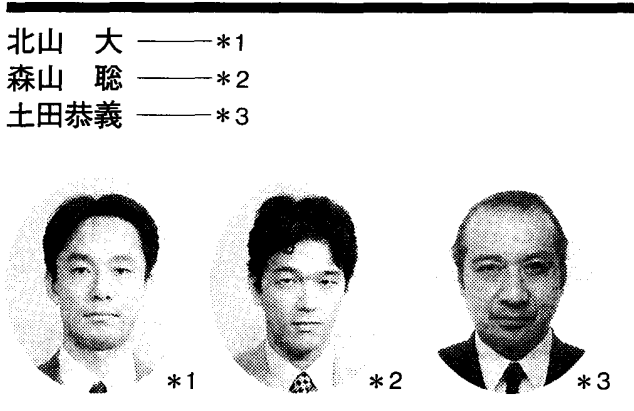

Hiroshi KITAYAMA

Satoshi MORIYAMA

Yasuyoshi TSUCHIDA

This report describes the interior finishing system to prevent hospital infections. This system's finishing materials have an antibacterial activity and chemical resistance, and are easy to clean, First, their efficiencies were evaluated by three laboratory tests. Next, a field test was carried out by putting them to practical use. Finally, to check the durability of the antibacterial agent, the materials were washed, and subject to UV rays and abrasions. Then their antibacterial activities were evaluated. As the result, the durability of the antibacterial agent, and the effectiveness of this test method in evaluating the durability (of this agent) were confirmed.

キーワード

院内感染, 内装, システム, 開発研究, 抗菌性, 評価方法

Keywords

Hospital infections, Finishing, System, Research and development,

Antibacterial activity, Evaluation method

\section{1.はじめに}

近年、病院や医療福祉施設等において、メチシリン而性黄色ブド ウ球菌（MR S A）をはじめとする環境污染菌による院内感染に対 して、医療従事者の関心のみならず社会的にも関心が高まっている。 医療分野では、院内感染の経路に対し、多種多様な対策がなされて いるが、感染経路は複雑で多岐にわたるため、全ての感染経路に対 する対策を講じることは困難である。このことから、医療以外の分 野からの対策が必要とされており、建築分野においても、抗菌性建 材や空調機器の開発・塞用化等様々な対策が行われている。しかし、 これらの対策が室内環境向上に及汪寸効果を定量的汇評価する方 法が確立されていない等の理由により、妥当性のある対策は確立さ れていないのが現状である。

著者らは、建築の分野から院内感染対策を行うことを目的とし、 室内環境の清浄化を目指した内装材の開発汇着手し、医療機関一の 実態調查や既設医療施設で実地試験、内装材等の室内環境に対寸 る影響の評価方法に関寸る検討を重ね、医療現場の要求に呼応した 「院内感染対策用内装システム」を開発したので報告する。

本報告は、これまでに報告したもの まとめたものである。

\section{2. 本システムの概要}

\section{1 本システムの箱想}

従来の床、壁、天井に使用されている内装材は、環境污染菌に対 寸る増殖抑制効果（抗菌性）や、病院や医療福祉施設等で使用され
ている消毒・滅菌剤（アルコール・ホルマリン等）汇対する耐薬品 性に乏しく、付着した血液等の污れが落ちにくい等の欠点があり、 室内の環境悪化の原因となる等の問題があった。このことから、本 システム及びその内装材は、以下の3つの性能を有寸るものとした。 (1抗菌性 : MRS A や緑膿菌の菌数学抑える性能。長期の持続性、 かつ人体への安全性を有するものとする。

(2)耐薬品性 : 病院や医療福祉施設等で使用する様々な消毒・滅菌剤 に侵されない性能。

(3污れ除去性 : 付着したゴミや污れが容易に除去だきる性能。

\section{2 本システムの鋪成}

図 1 に本システムの構成内装材とその性能を示す。本システムは、 病院や医療福祉施設等の部屋内部の床、壁、天井に、2.1 (1) (3)の 性能を有する内装材を用い、建具、設備機器、手摺等の表面に同様 の性能を有子るクリヤーコーティング材を塗布し、巾木部分に「塗 床サニタリー工法」を取り入れるものとした。「塗床サニタリーエ 法」注、塗床と巾木との取合い部索、R面木とフィット巾木で構成 寸るこ上により、シームレスに立ち上げる工法であり、埃溜まりを 防止することができる。また、R面木とフィット巾木の材質がフレ キシブルであるため、不陸のある休下地や壁洏おいても施工が可能 である。以下に各構成内装材について述べる。いずれの内装材も、 人体一の安全性が高い無機質銀系抗菌剤を主として配合している。

1）塗床材: 無機質銀系抗菌剂学配合したエポキシ樹脂系複色塗床 材。抗菌性、耐薬品性、污れ除去性を汢じめ、耐摩耗性、耐衝撃性 等に優れる。色調注複色上単色があり、選択寸ることができる。
*1 (株) フジタ技術研究所 研究員

(厂224 横浜市都筑区大棚町74)

$* 2$ (株) フジタ技術研究所 研究員

*3 (株) フジタ技術研究所 グループリーダー
*1 Research Engineer, Fujita Corporation Technical Research Institute

*2 Research Engineer, Fujita Corporation Technical Research Institute

*3 Group Leader, Fujita Corporation Technical Research Institute 
2) 長尺塩ビシート：高い抗菌性、耐薬品性、耐摩耗性を持ち、防 滑性に優れる。

3) ビニルクロス:従来のビニルクロスの構成のうえに無機質銀采 抗菌剤をコーティングした透明フィルムを積層している。フィルム により耐薬品性、污狆除去性汇優孔、高い抗菌性を有寸る。（無機 質 1 級壁紙、壁装材料第 0005 号認定)

4) 内装用塗料及びクリヤーコーティング材: 水性反応硬化型樹脂 汇銀系抗菌剤を配合した特殊塗料。水性反応硬化型樹脂住、低臭で あり、また、強固な塗膜を形成するため、高い耐薬品性、污れ除去 性を有する。下地処理材にも抗菌剂を配合しており、塗膜に傷等が ついた場合に沶い下、抗菌性発揮寸る。(防火材料基材同等第 0001 号認定)

5) 床用ワックス:水性反応硬化型樹脂汇銀系抗菌剤を配合した床 用クリヤーコーティング材。強固な塗膜を形成し、低臭でしかも施 工が簡単なため張床、塗床のメンテナンス材として最適な材料であ る。耐久性注通常のワックス比心優れている。

\section{3. 構成内装材の性能評価試験}

先ず、各構成内装材の性能を評価、確認する目的で、抗菌性試験 及び耐薬品性試験を行った。

\section{1 抗囷性試験 (滴下法)}

1) 試験方法

試料表面に、所定の菌による菌液 $(0.5 \mathrm{cc})$ を滴下し、温度 $27^{\circ} \mathrm{C} 、$ 湿度 70〜80\%の条件下で培養し、24 時間経過後の菌数を測定した (滴下法)。試料として、本システムの構成内装材から、塗床材、 ビニルクロス、内装用塗料（以下、抗菌性内装材）及び各々の材料 と同材質の内装材（以下、非抗菌性内装材）を選定し、試料寸法は $50 \mathrm{~mm} \times 50 \mathrm{~mm}$ とした。菌種は、院内感染にお讨る代表的菌種であ るMR S A （グラム陽性）、緑膿菌（グラム陰性）とした。試験は、 (財) 食品薬品安全センターにて実施した。

\section{2) 試験結果}

試験の結果を表 1 亿示寸。いずれの菌種、試料の場合も、抗菌性 内装材に打汀菌数は、非抗菌性内装材に扔汁る菌数と比べ非常に 小さい数值を示していることがわかる。このことから、抗菌性内装 材注非抗菌性内装材比比心、MR S A 、緑膿菌に対して高い抗菌性 を有するといえる。

\section{2 抗囷性試験（ハロ一法）}

\section{1) 試験方法}

一定量の菌を塗布した寒天培地上汇試料を置き、試料から寒天培 地中に溶出する抗菌剤により形成される発育阻止帯 (ハロー) の有 無により、抗菌性を評価した（図 2 参照）。菌種注MR S A、大腸 菌等とし、試料计内装用塗料とし、抗菌性内装材及び非抗菌性内装 材を用いた。試験は、(財) 食品薬品安全センターにて実施した。

\section{2) 試験結果}

試験の結果、抗菌性内装材に注明確なハローを確認できた一方、 非抗菌性内装材汇注八ローが形成されなかった。このことから、抗 菌性内装材は非抗菌性内装材に比心゙高い抗菌性を有するといえる。

\section{3 耐薬品性試験}

1) 試験方法

試料表面に試薬 $(2.0 \mathrm{cc})$ を滴下し、24 時間放置した後、滴下部 分を拭き取り変化を観察した。試料注、塗床材、ビニルクロス、内 装用塗料とし、抗菌性内装材及び非抗菌性内装材を用いた。

\section{2) 試験結果}

試験の結果を表 2 亿示寸。表から、いずれの薬品、試料の場合に おいても抗菌性内装材は、非抗菌性内装材に比べ変化が少ないこと がわかる。このことから、通常院内て使用される薬品に対し、抗菌 性内装材は、非抗菌性内装材に比べ安定した耐薬品性を有している 上い光る。

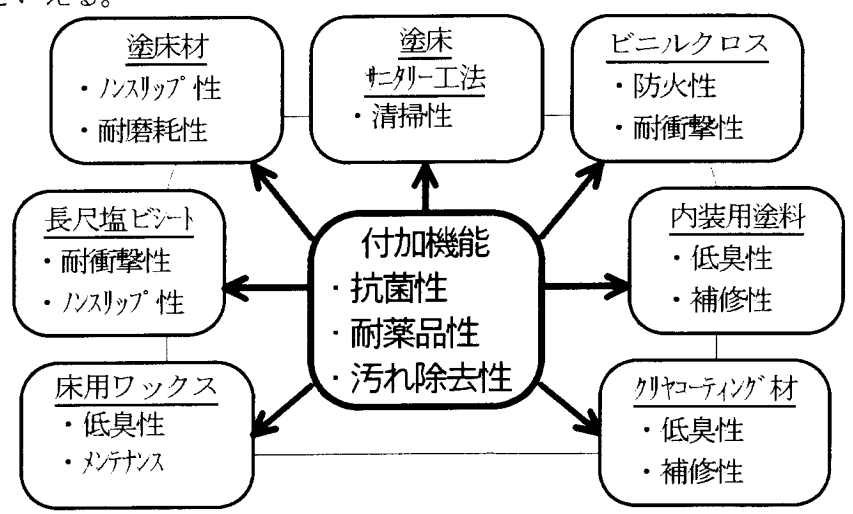

図1 本システムの構成内装材とその性能

表 1 抗菌性評価試験結果（(財)食品薬品安全センター)

\begin{tabular}{|c|c|c|c|c|c|}
\hline \multirow{2}{*}{\multicolumn{2}{|c|}{ 試料 }} & \multicolumn{2}{|c|}{ MR S A } & \multicolumn{2}{|c|}{ 緑膿菌 } \\
\hline & & 初発菌数 & 24 時間後 & 初発菌数 & 24 時間後 \\
\hline \multirow{2}{*}{ 塗床材 } & 抗菌 & $2.6 \times 10^{7}$ & $<10^{1}$ & $5.5 \times 10^{7}$ & $2.2 \times 10^{5}$ \\
\hline & 非抗菌 & $2.6 \times 10$ & $5.2 \times 10^{7}$ & $5.5 \times 10^{7}$ & $9.6 \times 10^{7}$ \\
\hline \multirow{2}{*}{ ビ二将叹 } & 抗菌 & $2.6 \times 10$ & $5.2 \times 10^{2}$ & $5.5 \times 10$ & $1.0 \times 10^{4}$ \\
\hline & 非抗菌 & $2.6 \times 10$ & $1.0 \times 10^{4}$ & $5.5 \times 10$ & $1.6 \times 10^{6}$ \\
\hline \multirow{2}{*}{ 内装用塗料 } & 抗菌 & $2.6 \times 10$ & $<10^{1}$ & $5.5 \times 10^{7}$ & $<10^{1}$ \\
\hline & 非抗菌 & $2.6 \times 10^{7}$ & $5.1 \times 10$ & $5.5 \times 10$ & $5.1 \times 10^{7}$ \\
\hline
\end{tabular}

発育阻止帯（ハロー）

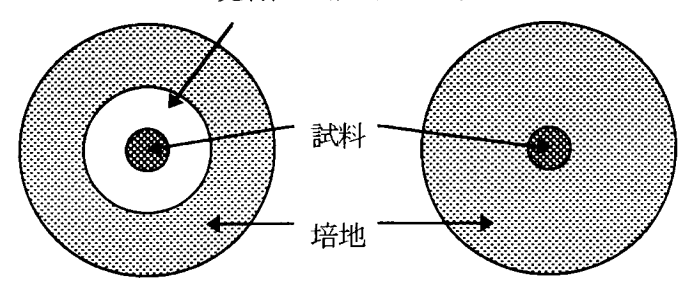

抗菌性内装材（抗菌性あり）非抗菌性内装材（抗菌性なし）

図2 ハロー法の概要

表 2 耐薬品性試験結果

\begin{tabular}{|c|c|c|c|c|c|c|}
\hline 内装材 & \multicolumn{2}{|c|}{ 塗床材 } & \multicolumn{2}{|c|}{ ビニルクロス } & \multicolumn{2}{|c|}{ 内装用塗料 } \\
\hline 薬品 & 抗菌 & 非抗菌 & 抗菌 & 非抗菌 & 抗菌 & 非抗菌 \\
\hline 工多ノール & $\mathrm{O}$ & $\bigcirc$ & 0 & $x$ & $O$ & $x$ \\
\hline 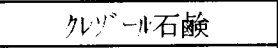 & $\triangle$ & $\triangle$ & $\triangle$ & $x$ & 0 & $\triangle$ \\
\hline 次亚塩素酸十トリ方么 & $\mathrm{O}$ & 0 & 0 & $x$ & 0 & 0 \\
\hline 塩化ベンザルコこ方ム & 0 & 0 & 0 & $x$ & 0 & 0 \\
\hline 彻少 & $\mathrm{O}$ & 0 & 0 & 0 & 0 & 0 \\
\hline ヒビデ & 0 & 0 & 0 & $\triangle$ & 0 & 0 \\
\hline
\end{tabular}

$\bigcirc$ :変化なし $\triangle$ :やや変化あり $\times$ : 変化あり 


\section{4. 実地における性能評価試験}

次に、実際の使用状況下に扔ける性能評価を行う目的で、横浜市 のY高齢者施設の隔離室に本システムの塗床材、ビニルクロス、内 装用塗料等（抗菌性内装材）を施工し、室内空間の環境を対象とし た下記の試験を実施した。なお、この施設においては、消毒薬を用 い、1 日 1 回モップ洗浄による休面及び壁面の消毒清掃を実施して いる。

\section{1 抗国性評価試験の概要}

1) 試験方法

施工から約 1 年経過後、図 3 の(1) 及び(2) (塗床材施工部分) でス タンプ法により $36 \mathrm{c} \mathrm{m}$ 当たりの付着菌を採取し、24 時間 $37^{\circ} \mathrm{C}$ で培 養後、菌数を測定した。な挔、採取場所には採取前 $24: 6.0$ 時間シャ ーレをかぶせることにより、落下菌及び空調や人の動き等による影 響を遮断した。また、比較する目的で採取場所近傍渄抗菌性内装 材を設置し、同様の試験を行った。対象菌種は一般生菌とした。試 料数は 2 とし、測定值の平均值を算出した。

2)試験結果

一般生菌に関する結果を図 4、5 亿示す。図から、抗菌性内装材 における菌数法非抗菌性内装材に打汀る菌数に比べ明らか沉少な い傾向が確認できる。このことから、実際の施設の使用条件下にお いて、抗菌性内装材は非抗菌性内装材に比べて抗菌性を発揮するこ とが確認できる。

一方、シャーレをかぶせた時間と菌数との間に一定の傾向がみら れないことから、試験結果には、建材の抗菌性以外の他の要因が影 響していると考えられる。スタンプ法には、菌捕集力が一般的に低 く、試料の材質や表面形状汇影響を受けや寸いこと等の影響も考号 られる。

\section{2 目視钼察の概要}

施工から約 1 年経過後、図 3 の床面及び壁面において目視による 観察を行った。隣接する部屋沲工した非抗菌内装材と比較した結 果、抗菌性内装材には、非抗菌性内装材に生じる変色や污れの付着、 劣化等は見らなかった。このことから、抗菌性内装材は、非抗菌性 内装材に比べ、より高い耐薬品性及び污れ除去性を有するといえる。

\section{5. 抗囷性の持続性に関する評価試験}

実際の使用条件下において抗菌性を評価するうえでは、抗菌性の 持続性を何らかの指標で客観的に評価することが重要と考えられ る。このため、病院や医療福祉施設等の日常の使用条件下における 抗菌性の持続性を評価することを目的とした、内装材の促進劣化試 験方法を提案し、以下の通り実施した。

\section{1 促進少化試験の概要}

促進劣化試験の概要を表 3 に示す。本試験は、JIS A 5663 ,A 6909 ，A 6921 亿準じ、病院、医療福祉施設等の日常の消毒清掃、紫 外線、磨耗等の内装材の劣化要因を再現したものである。試料は、 塗床材、ビニルクロス、内装用塗料とし、本システムの抗菌性内装 材を用いた。洗浄の場合の試験状況を一例として写真 1 亿示す。

試験の結果、洗浄の場合には、いずれの試料も変化は見られなか った。紫外線照射の場合に、一部試料において変色を確認した。

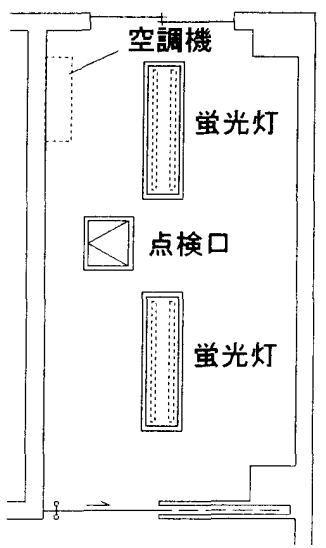

廊下

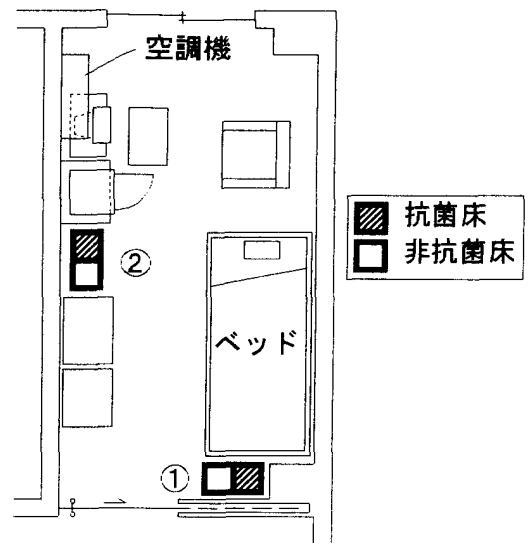

廊下

平面図

図3 隔離室におう沙るスタンプ法による菌採取位置

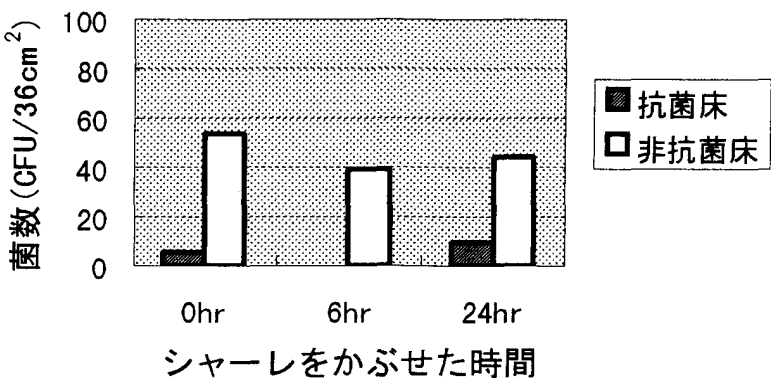

図4 スタンプ法による一般生菌数測定結果 (測定点 : 図 3(1)

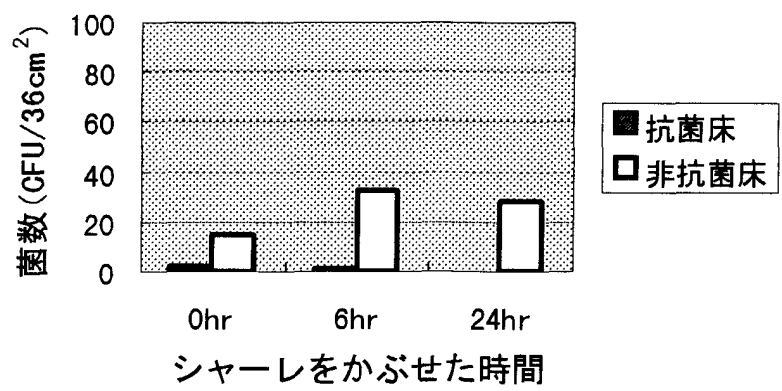

図5 スタンプ法による一般生菌数測定結果 (測定点 : 図 32)

表 3 促進劣化試験の概要

\begin{tabular}{|c|c|c|c|}
\hline 促進劣化方法 & 条件 & 仕様 & JIS の仕様 \\
\hline \multirow{5}{*}{ 洗浄 } & 洗浄試験機 & 右に準趐 & $A 6909, A 5663$ \\
\hline & 介在物 & $\begin{array}{c}\text { 水道水, 薬品(1) (4) } \\
\text { より選定 }\end{array}$ & 石酫水 \\
\hline & 荷重 & $800 \mathrm{~g} / 34.2 \mathrm{c} \mathrm{m}^{2}$ & $450 \mathrm{~g} / 34.2 \mathrm{c} \mathrm{m}^{2}$ \\
\hline & 往復回数 & 1,000 回 & 300 回 \\
\hline & アタッチメント & ガーゼ & ブラシ \\
\hline \multirow{2}{*}{ 紫外線照射 } & $7 x-ト ゙ x-タ$ & 右に準扰 & A6909, A6921 \\
\hline & 照射時間 & 250 時間 & 材質による \\
\hline 磨耗 & & 厚さの1,3 除去 & $=$ \\
\hline 促進劣化なし & - & -- & - \\
\hline \multicolumn{4}{|c|}{$\begin{array}{l}\text { *1(1)塩酸アルキルジアミノエチルグリシン } 0.2 \% \text { 水溶液 } \\
\text { (2)グルコン酸クロルヘキシジンアルコール } 0.5 \% \text { 溶液 } \\
\text { (3)塩化ベンザルコニウム } 0.2 \% \text { 水溶液 }\end{array}$} \\
\hline
\end{tabular}




\section{2 抗菌性評価試験の概要}

\section{1) 試験方法}

5.1 で促進劣化させた各試料 $(50 \mathrm{~mm} \times 50 \mathrm{~mm})$ の表面に各菌による 菌液 $0.5 \mathrm{ml}$ (初発菌数、十万) を滴下し、ボリエチレンフィルムを被 せ、24 時間経過後の菌数を測定した（密着法、図6参照）。また、 比較する目的で促進前の内装材（以下、促進劣化なし）及び各試料 々同材質て抗菌剤非配合の内装材（非抗菌性内装材）汇ついても同 様の試験を行った。对象菌種は院内感染に扔ける代表的菌種である MR S A及び緑膿菌とした。試料数は 2 とし、測定值の平均を算出 した。抗菌性試験は、（財）日本食品分析センターにて実施した。

2) 試験結果

試験結果の一例として、塗床材、緑膿菌の場合を図てに示す。図 から、非抗菌性建材の場合には、菌数が増加する一方、他のいずれ の促進劣化方法の場合も、促進劣化なしの場合上同様に菌数が減少 することがわかる。また、他の場合にも同様の傾向が確認できた。 このことから、いずれの促進劣化方法、試料、菌種の場合も、促進 劣化をさせていない試料と同様の抗菌性を有することがわかる。

一方、一部試料汸いて変色が発生していることから、実際の負 荷に比心゙て過剩な負荷がかかっている可能性があるといえる。この ことから、本試験の促進劣化方法上実際の使用条件との相関をさら に検討し、実験を継続的に実施するとともに、妥当性のある促進劣 化試験方法を確立する必要があるといえる。

\section{6. 適用事例}

1996 年 6 月現在、千葉県 $K$ 総合病院 (写真 2 ) 、広島県 $H$ 病院、 広島県 $\mathrm{K}$ 病院等数多くの物件に適用されている。今後も、病院をは じ方、老人保健施設、特別養護老人ホーム等医療福祉施設を対象に 幅広く適用寸る予定である。

\section{7.おわりに}

室内評価試験及び病院や医療福祉施設等の実際の使用条件下に お汀る試験で、本システムが十分に抗菌性、耐薬品性、污れ除去性 を発揮することを確認した。併せて、室内環境評価方法並びに新た に提案した促進劣化方法について一定の知見を得た。今後、これら の結果を踏まえ、さらに実地におりる評価試験等を継続するととも に、試験条件を含め評価方法の確立を目指していく計画である。

高齢化社会に入り、高齢者施設の増加が予想される。筆者らは、 今後、施設の目的・用途に応じた最適な環境を創造寸るこ上を目的 とし、本システムに適切な平面計画、設備計画、衛生管理、維持管 理を組み合わせ、総合的に高環境を創造することのできるシステム を研究・開発する予定である。

\section{参考文献}

1) 北山大、土田恭義 : 建材の抗菌性の評価方法に関寸る研究（この1）抗 菌性評価方法の比較検討、日本建築学会大会学術講演梗概集 $\mathrm{A}-1 、$, pp. 1425 $\sim 1426.1995 .8$

2）北山大、土田恭義、森山聡 : 建材の抗菌性の評価方法汇関寸る研究（之 の2）抗菌性の持続性評価汇関寸る考察、日本建築学会大会学術講演梗概集 A- 1 、 pp.1039 1040, 1996.9

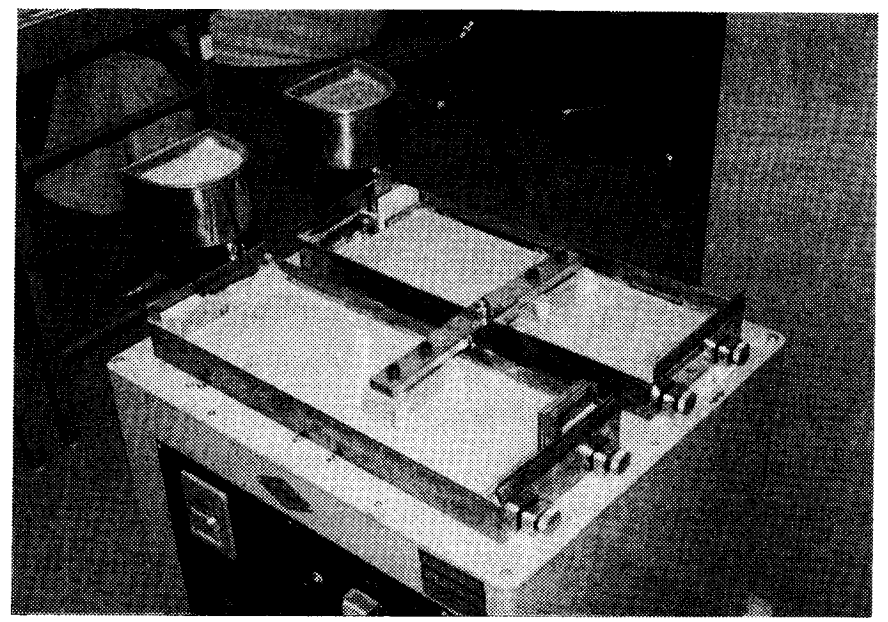

写真 1 促進劣化試験状況の一例（表 3 の洗浄の場合）

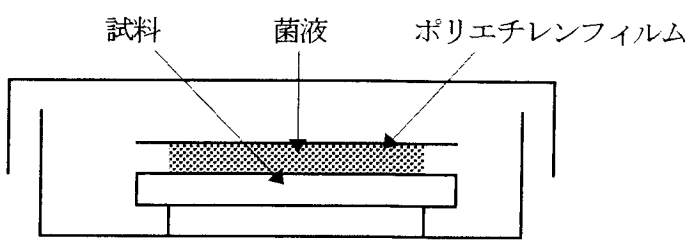

図 6 密着法の概要

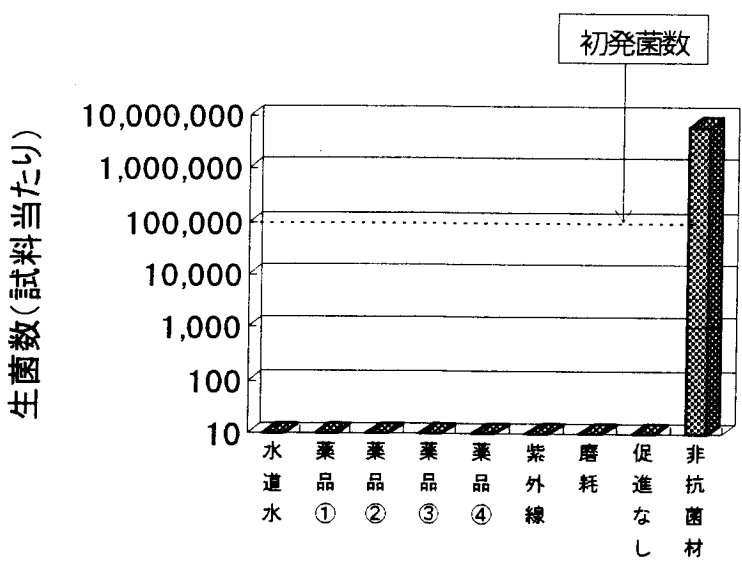

促進劣化方法

図7 促進劣化後の抗菌性試験結果の一例 （財）日本食品分析センター)

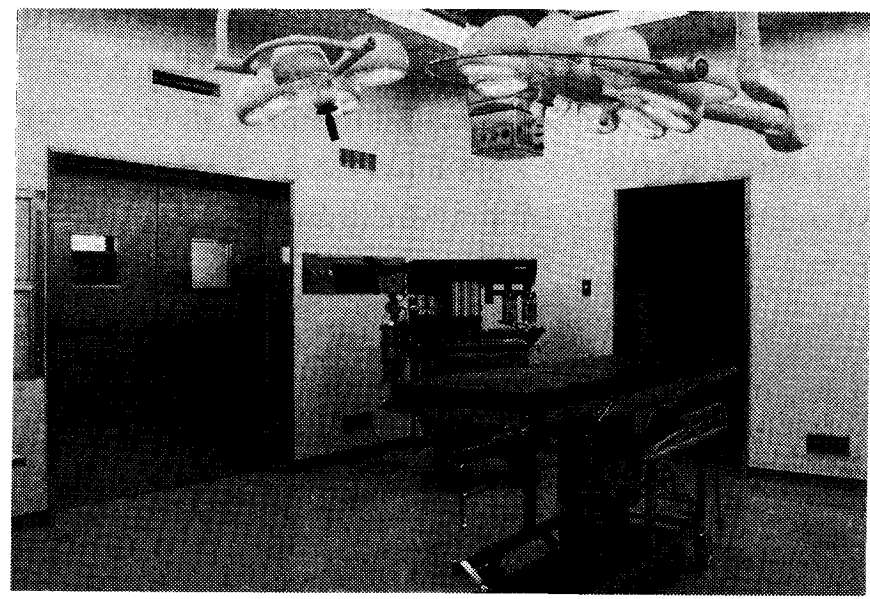

写真 2 千葉県 $\mathrm{K}$ 総合病院 手術室

[1996年 6 月28日原稿受理 1996年 9 月10日採用決定］ 